\title{
PENGEMBANGAN MODUL STATISTIKA BERBASIS QR CODE UNTUK MELATIH HIGH ORDER THINGKING SKILLS (HOTS) MAHASISWA
}

\author{
Anton Zulkarnain Sianipar', Saprudin ${ }^{2}$, Zulhalim ${ }^{3}$ \\ Teknik Informatika ${ }^{1}$, Manajemen $^{2}$, Sistem Informasi ${ }^{3}$ \\ STMIK Jayakarta ${ }^{1}$, Sekolah Tinggi Ilmu Ekonomi Jayakarta ${ }^{2}$, STMIK \\ Jayakarta $^{3}$ \\ antonz.jayakarta@gmail.com¹, saprudinmaksudi@gmail.com², \\ zulhalim@gmail.com ${ }^{3}$
}

\begin{abstract}
Abstrak: Penelitian ini bertujuan untuk mengembangkan modul statistika berbasis qr code dan melatih high order thinking skills mahasiswa. Rancangan penelitian berupa penelitian pengembangan dengan model A-D-D-D-I-E, yaitu observasi dan pengumpulan data, perencanaan pengembangan produk, tahap penciptaan produk awal pengujian lapangan awal dengan cara melakukan tinjauan para ahli mengenai produk yang didesain baik dalam hal modul bahan ajarnya, revisi produk awal. Pengembangan modul ini berdasarkan kelayakan isi, penyajian, dan Bahasa oleh validator ahli. Uji validitas yang dilakukan adalah validasi isi, penyajian, dan Bahasa modul kemudian direvisi dan diimplementasikan pada mahasiswa program studi Teknik Informatika. High order thinking skills (HOTS) mahasiswa dianalisi dengan uji parametrik dengan uji t test menggunakan software SPSS. Hasil dari Penelitian ini yaitu: (1) kelayakan pengembangan modul statistika berbasis QR Code dikategorikan baik; (2) higher order thinking skill (HOTS) mahasiswa meningkat; (3) dari empat Aspek higher order thinking skill (HOTS) kemampuan logika dan penalaran mengalami peningkatan tinggi diikuti kemampuan analisis, kemampuan evaluasi, dan kemampuan kreasi.
\end{abstract}

Kata kunci: modul statistika; qr code; HOTS

\begin{abstract}
This study aims to develop a qr code-based statistics module and train students' high order thinking skills. The research design is in the form of development research with the A-D$D-D-I-E$ model, namely observation and data collection, product development planning, the initial product creation stage, initial field testing by conducting expert reviews of welldesigned products in terms of teaching material modules, initial product revisions. The development of this module is based on the feasibility of content, presentation, and language by expert validators. The validity test carried out was the validation of the content, presentation, and language of the module which was then revised and implemented in students of the Informatics Engineering study program. Students' high order thinking skills (HOTS) were analyzed with a parametric test with a $t$ test using SPSS software. The results of this study are: (1) the feasibility of developing a statistics module based on QR Code is categorized as good; (2) the students' higher order thinking skills (HOTS) increased; (3) out of the four aspects of higher order thinking skill (HOTS), logic and reasoning skills experienced a high increase followed by analytical skills, evaluation abilities, and creative abilities.
\end{abstract}

Keywords: statistics module; QR Code; HOTS

Ciptaan disebarluaskan di bawah Lisensi Creative Commons Atribusi 4.0 Internasional. 


\section{PENDAhUluaN}

Statistika merupakan mata kuliah wajib di kampus STMIK Jayakarta. Mata kuliah statistika di pelajari baik di program studi Sistem Informasi maupun di program studi Teknik Informatika. Masih banyak mahasiswa yang kesulitan memahami mata kuliah statistika (Hanggara \& Amelia, 2018; Putri \& Suryati, 2017)

Hal ini dirasakan sama oleh peneliti Ketika mengajar mata kuliah statistika, yaitu masih rendahnya hasil belajar statistika dalam beberapa periode terkahir. Mata kuliah statistika merupakan mata kuliah yang nantinya diharapkan dapat mampu membantu mahasiswa Ketika tugas akhir dalam mengolah data. Dalam mata kuliah statistika dipelajari analisis pengolahan data yang dapat mencari pengaruh maupun regresi, korelasi yang mencari hubungan antar variabel. Dari hasil wawancara dengan beberapa mahasiswa yang mengalami kesulitan dalam memahami konsep statistika adalah sulitnya memahami rumus yang ada, rumus yang ada dianggap sulit diterjemahkan dan diaplikasikan dalam kehidupan sehari - hari.

Quick Response Code atau yang sering kita sebut $Q R$ Code atau dapat di terjemahkan menjadi kode respon cepat (Hidayat, Kusuma, \& Tritoasmoro, 2019). QR Code terdiri dari kumpulan batang hitam dengan latar putih, dan merupakan kode unik untuk setiap masing - masing karakternya. Dengan teknologi QR Code memudahkan dalam respon cepat menuju suatu alamat URL. QR Code tersebut dapat diaplikasikan dalam Pendidikan, misal untuk menuju alamat pembelajaran tertentu terkait materi tertentu.

Kemampuan berpikir tingkat tinggi (HOTS) merupakan kemampuan

Berdasarkan uraian di atas, diperlukan adanya bahan aja yang dapat menjadi alternatif buku pegangan bagi mahasiswa selain bukut cetak. Bahan ajar yang dapat dikembangkan adalah modul. Modul adalah bahan ajar cetak yang disusun untuk dapat dipelajari oleh siswa secara mandiri tanpa ada bimbingan dari guru karena telah disajikan secara sistematis dan dikembangkan sesuai perkembangan siswa (Prastiwi \& Pendahuluan, n.d.). bahan ajar yang dibutuhkan bukan hanya modul yang dirancang seperti biasa, namun harus mampu menampung penggunaan teknologi informasi serta mampu melatih kemampuan berpikir tingkat tinggi mahasiswa. Untuk itu modul yang akan dikembangkan adalah modul yang berbasis QR Code.

\section{METODE DAN MATERI}

Modul ini dikembangkan dengan model ADDIE. Model ini terdiri atas lima langkah, yaitu: (1) analyze, (2) design, (3) development, (4) implementation, dan (5) evaluation (Branch, 2009). Pemilihan model ini didasari atas pertimbangan bahwa model ini dikembangkan secara sistematis dan berpijak pada landasan teoretis desain pembelajaran. Model ini disusun secara terprogram dengan urutan-urutan kegiatan yang sistematis dalam upaya pemecahan masalah belajar yang berkaitan dengan strategi penyampaian pembelajaran yang sesuai dengan kebutuhan dan karakteristik peserta didik. Secara visual, kelima tahapan model ADDIE dapat dilihat pada Gambar.

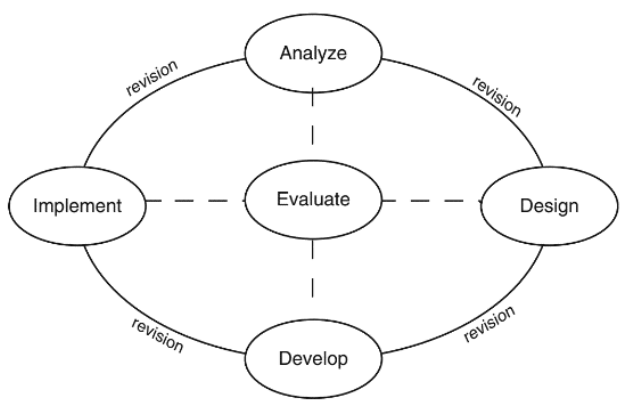

Gambar 1 Model ADDIE

Pada tahap analisis (analyze), meliputi kegiatan analisis kebutuhan belajar mahasiswa dalam memahami materi statistika. Pada tahapan perancangan (design), menyusun unsur-unsur yang memudahkan mahasiswa dalam memahami materi statistika. Pada tahapan pengembangan (development), dilakukan dengan membuat modul statistika menggunakan aplikasi SPSS. Pada tahapan implementasi (implementation), kegiatan dilakukan uji coba terbatas modul statistika terhadap mahasiswa. Selanjutnya, pada tahapan evaluasi (evaluation), 
dilakukan revisi modul statistika yang dihasilkan berdasarkan hasil uji coba. Penelitian ini dilakukan di STMIK Jayakarta, pada program studi Teknik Informatika.

\section{Statistika}

Statistika berperan untuk alat menghitung besarnya anggota sampel yang diambil dari suatu populasi, alat untuk menguji validitas dan reliabilitas instrument sebelum instrumen tersebut digunakan dalam penelitian, dan sebagai Teknik menyajikan data (Sugiyono, 2019)

\section{QR Code}

QR code banyak digunakan di berbagai bidang, seperti spanduk jalan, metode pembayaran dan lain - lain Teknologi QR code masih jarang digunakan dalam Pendidikan. Kemudahan akses penelusuran alamat dalam penggunaan QR code harusnya dapat lebih di kembangkan. Salah satu contoh akses QR Code untuk mempelajari materi analisis regresi adalah sebagai berikut :

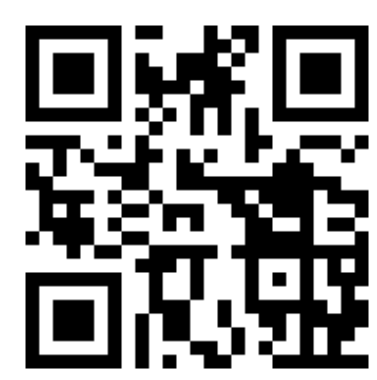

Gambar 2 QR Code Alamat Youtube Analisi Regresi

\section{HOTS}

Kompetensi yang dimiliki kemampuan berpikir tingkat tinggi yaitu berpikir kritis (criticial thinking), kreatif dan inovasi (creative and innovative), kemampuan berkomunikasi (communication skill), kemampuan bekerja sama (collaboration), dan kepercayaan diri (confidence) (Ariyana, Pudjiastuti, Bestary, \& Zamroni, 2019)

\section{PEMBAHASAN DAN HASIL}

\subsection{Angka}

Angka lima atau lebih digit dikelompokkan dalam blok tiga digit menurut spasi, mis. 12.345. Pastikan Anda menyebutkan unit saat berlaku. Perhatikan angka penting dan hindari angka digit panjang yang tidak perlu.

\subsection{Unit}

Gunakan satuan SI atau satuan turunan SI.

\subsection{Matematika}

Perhatian yang luar biasa harus diambil dalam menyiapkan naskah naskah matematika. Semua matematika harus dapat dibaca, tepat dan selaras. Berikut ini menunjukkan contoh menempatkan persamaan dalam teks:

$$
\mathrm{Y}=\mathrm{A}+\mathrm{Bx}+\mathrm{Cx}^{2}
$$

di mana $\mathrm{Y}$ dan $\mathrm{X}$ adalah variabel output dan input, masing-masing; A dan B adalah konstanta.

Karakter miring harus digunakan sebagai variabel. Di sisi lain, karakter "Times New Roman" harus digunakan sebagai fungsi mis. dosa, exp, log.

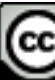


Seperti di atas, persamaan harus di margin kiri; sedangkan nomor persamaan menampilkan ekspresi dengan angka Arab dalam tanda kurung harus berada di margin kanan. Letakkan garis spasi sebelum dan sesudah persamaan.

\subsection{Ilustrasi}

Tabel I. Nama Tabel yang digunakan

\begin{tabular}{c|cccccc}
\hline Sr. No. & Heading1 & Heading 2 & Heading 3 & Heading 4 & Heading 5 & Heading 6 \\
\hline & & & & & & \\
& & & & & \\
\hline
\end{tabular}

Gunakan gambar dan tabel untuk menggambarkan suatu proses atau data secara rinci. Hindari mewakili aspek yang sama dari data yang sama menggunakan gambar dan tabel, semuanya. Setiap ilustrasi harus direferensikan setidaknya dalam satu paragraf. Tabel 1 menunjukkan contoh representasi tabel, sedangkan Gambar 1 menunjukkan contoh representasi gambar. Berikan informasi yang diperlukan untuk memungkinkan pembaca memahami ilustrasi. Sorotan dapat digunakan untuk menekankan informasi penting dan signifikan yang terkandung dalam ilustrasi.

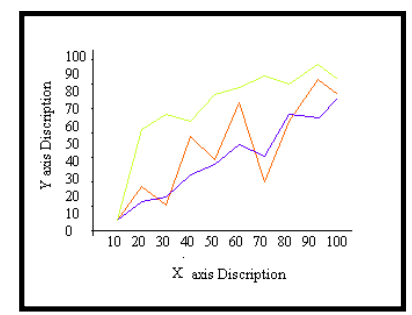

Gambar 1. Contoh keterangan gambar Satu Kolom

\section{KESIMPULAN}

Berdasarkan hasil analisis data dapat disimpulkan bahan ajar berupa modul statistik yang dihasilkan telah valid, praktis dan efektif dengan tingkat kevalidan sebesar 82,33\%, dengan kategori sangat baik, tingkat kepraktisan sebesar 81,73\% dengan kategori baik dan persentase ketuntasan secara kalsikal sebesar 72,73\% dalam kategori baik sehingga dapat disimpulkan bahwa modul yang dikembangkan efektif.

Berdasarkan hasil penelitian, maka peneliti dapat menyampaikan beberapa saran sebagai berikut: Bahan ajar berupa modul statistik pendidikan berbasis CTL perlu disempurnakan kembali, jika memang hal tersebut bermanfaat dan menghasilkan produk yang lebih berkualitas. Bagi pembaca yang tertarik dengan penelitian ini dapat mengembangkan modul berbasis CTL pada materi pembelajaran yang berbeda atau pada mata kuliah yang lain.

\section{REFERENSI}

[1] Ariyana, Y., Pudjiastuti, A., Bestary, R., \& Zamroni. (2019). Buku Pegangan Pembelajaran Berorientasi pada Keterampilan Berpikir Tingkat Tinggi. In Direktorat Jenderal Guru dan Tenaga Kependidikan. Direktorat Jenderal Guru dan Tenaga Kependidikan.

[2] Branch, R. M. (2009). Instructional Design: The ADDIE Approach. Retrieved from http://weekly.cnbnews.com/news/article.html?no=124000

[3] Hanggara, Y., \& Amelia, F. (2018). Pengembangan Modul Statistik Pendidikan Berbasis Ctl Untuk Meningkatkan Kompetensi Mahasiswa Universitas Riau Kepulauan Batam. PYTHAGORAS: Jurnal Program Studi Pendidikan Matematika, 7(2), 1-11. https://doi.org/10.33373/pythagoras.v7i2.1261

[4] Hidayat, M. T., Kusuma, P. D., \& Tritoasmoro, I. I. (2019). Pengembangan Modul Client Pada Sistem Parkir Pintar Berbasis Quick Response (Qr Code) Development of Client System Smart Parking Based Quick Response Code

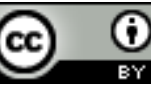

Ciptaan disebarluaskan di bawah Lisensi Creative Commons Atribusi 4.0 Internasional. 


\section{Journal of Information System, Applied, Management, Accounting and Research.}

http://journal.stmikjayakarta.ac.id/index.php/jisamar, jisamar@stmikjayakarta.ac.id , jisamar2017@gmail.com e-ISSN: 2598-8719 (Online), p-ISSN: 2598-800 ( Printed), Vol. 5 No.1 Februari 2021

(Qr Code). E-Proceeding of Engineering, 6(1), 1463-1469.

[5] Prastiwi, A., \& Pendahuluan, I. (n.d.). Pengembangan Modul Fisika Berbasis Masalah Untuk Meningkatkan High Order Thinking Skills ( HOTS ) Siswa SMA. 1-6.

[6] Putri, N. W. S., \& Suryati, N. K. (2017). Pengembangan Modul Statistika Berbasis Spss Di Stmik Stikom Indonesia. 15(2), 168-184.

[7] Sugiyono. (2019). Metode Penelitian Kuantitatif (2nd ed.). Yogyakarta.

[8] Sommerville.Ian (2011) "Software Engineering" 9th Edition, Published by Addison-Wesley.

[9] Verdi Yasin (2012). Rekayasa Perangkat Lunak Berorientasi Objek. Jakarta : Mitra Wacana Media

[10] N. C. Ashioba , R. E. Yoro.” RSA Cryptosystem using Object-Oriented Modeling Technique”. International Journal of Information and Communication Technology Research. Volume 4 No. 2, February 2014. ISSN: 2223 4985, Published by IRPN Press Cornell University.

[11] Julinda Maya Paramudita, Verdi Yasin (2019) "Perancangan aplikasi sistem penyewaan alat berat (studi kasus: PT. Jaya Alam Sarana Jakarta)". Journal of Information System, Applied, Management, Accounting and Research. eISSN: 2598-8719, p-ISSN: 2598-8700, Vol.3, No.1 (2019)

http://journal.stmikjayakarta.ac.id/index.php/jisamar/article/view/73 